\title{
Intrapreneurial behavior: an empirical investigation of personality traits
}

\author{
Muhammad FARRUKH \\ Institute of Graduate Studies, SEGi University, Kota Damansara, Malaysia \\ mfarrukhiqbal@hotmail.com \\ Chong Wei YING \\ Graduate School of Business, SEGi University, Kota Damansara, Malaysia \\ Shaheen MANSORI \\ INTI International University, Nilai, Malaysia
}

\begin{abstract}
The study investigated the impact of personality traits on intrapreneurial behavior. Data was collected from 306 employees working in higher education institutions. Structural equation modeling technique was utilized with the help of SmartPLS software. The findings of the study revealed a positive association of extroversion, openness to experiences and emotional stability with intrapreneurial behavior, while a negative impact of conscientiousness, agreeableness on intrapreneurial behavior was recorded. The findings of this study have several implications in the context of HEIs. To enhance the intrapreneurial behavior in the higher educational institutes, the management of the institutions should take positive steps to ensure that employees have personality traits which have shown a significant impact on the intraprenuerial behavior in this study. One strategy top management could consider is that, at the time of recruitment, preference should be given to candidates with higher levels of extroversion, openness to experience and emotional stability. However, among all the traits, the most indicative marker is extroversions followed by emotional stability. Therefore, hiring employees with high levels of extroversion and emotional stability could facilitate more intraprenuerial behavior, which ultimately, will help improve the performance of HEIs. This study with its focus on the micro level foundations of intrapreneurial behavior is one of the first studies in the domain of intrapreneurship.
\end{abstract}

Keywords: intrapreneurship, five factor model of personality, higher educational institutes, structural equation modeling, SmartPLS.

Please cite the article as follows: Farrukh, M., Ying, C. and Mansori, S. (2016), "Intrapreneurial behavior: an empirical investigation of personality traits", Management \& Marketing. Challenges for the Knowledge Society, Vol. 11, No. 4, pp. 597-609. DOI: 10.1515/mmcks-20160018.

\section{Introduction}

Intrapreneurship is accepted by academics and practitioners as a legitimate route towards increased levels of organizational performance (Hayton et al., 2013). Current research suggests the scope of intrapreneurship is widening as organizations not traditionally recognized as being entrepreneurial now are required to become oriented towards CE in order to survive (Phan et al., 2009, Cantaragiu and Hadad, 2014). 
Intrapreneurship is embodying risk taking, pro-activeness and radical product innovations. These intrapreneurship activities can improve organizational growth and profitability and depending on the company's competitive environment, their impact may increase over time. It is a broad concept at the centre of which is the process of organizational renewal (Lekmat and Chelliah, 2014)

Intrapreneurship is increasingly becoming the concern for many organizations as that consider it a competitive strategy (Kuratko et al., 2001; Stevenson and Jarillo, 1990, Hadad, 2015). Not only organizational leaders but academic leaders are trying to find out a way of incorporating creativeness in their human capital as they can be a source of competitive advantage to the organizations (Kenney and Mujtaba, 2007).

Research in this area, according to Moriano et al. (2009) has focused on identifying the variables that influence the Entrepreneurial behavior of individuals. At the organizational level, the importance of different factors is emphasized, such as the size of the organization, structure, adequate use of rewards, managerial support, and availability of resources (Antoncic and Hisrich, 2001; Zahra and Covin, 1995). However, in relation to individual behavior within organizations, the research is limited; therefore, the focus of this study is to investigate the association between the personality traits of the employees and intrapreneurial behavior.

\section{Research issue}

The performance of the higher educational institutes of Pakistan has been a longstanding issue since last six decades. Pakistan has been ranked 50th out of 50 countries, with an overall score of 9.2 by Quacquarelli Symonds (QS), a British ranking agency. Despite the government's claims to have invested billions in the country's education system, Pakistan secured the lowest ranking of the fifty countries included in the list (QS Higher Education System Strength, 2016). Moreover, according to Times Higher Education World University rankings, no Pakistani university made it to the list of top 500 universities in the world (World University Rankings, 2016).

This issue of low performance of the state government for HEIs has made the organizations' environments difficult to adapt to the changing needs of the 21st century and impossible to keep up with globalization. This deficiency in performance demands the HEI to be more responsive to the stakeholder of the institutes. Therefore, the conventional systems of HEIs require some progressions to embrace some entrepreneurial models to conquer the lack of performance. There is a dire need to know the factors which might help the HEIs to become more entrepreneurial in their operations to deliver the desired services to stakeholder. An In-depth study of the literature showed several factors which might help the organizations to become entrepreneurial these factors include organization level and Individual level. Many organizational factors seem to be instrumental in the creation of entrepreneurial organization behaviour (Goodale et al., 2011; Sinha and Srivastava, 2013; Yildiz et al., 2004; Zahra 1995; Zahra, 1993).

Individual level factors concerns individual antecedents of entrepreneurship and focuses on investigating why do some people, but not others, become entrepreneurs or recognize and exploit opportunities. However, not so much is written on the individual factors which are affecting the entrepreneurial behavior in organization, personality traits are one of the main factors which may affect the behaviour of individuals to become intraprneur. The dimensions of intrapreneurship 
innovativeness, and risk taking belong to individuals (de Jong et al., 2011) and knowing the antecedents of human behavior has become one of the tinted areas of research. This study is the sequence of many other previous studies which were conducted to identify the factors that are affecting the entrepreneurial behavior in the organizations, in doing so, this study investigated the relationship between the personality traits (five factor model of personality will be utilized) and intrapreneurial behavior.

\section{Literature review Intrapreneurship and higher education institutes}

The circumstances that permit room corporate enterprise (CE) in a corporate business environment may likewise make the same conditions for Intrapreneurship to be effective inside the setting of Higher Education Institutions since researchers have the sentiment that corporate endeavors thrive in a quickly changing environment e.g. (Covin and Slevin, 1991; Miller and Friesen, 1984; Zahra, 1991) and the same is that confronting Higher Education Institutions today (Wong, 2008). Zahra (1991) advocated that entrepreneurial practices are strengthened in dynamic, antagonistic and heterogeneous environment.

According to Nielsen et al. (1985), intrapreneurial practices work best in a dynamic work environment. One approach to manage performance of HEIs is to consider it to an industry within business sector. This approach may help the management to look into the changing environment accordingly. With regards to HEIs customer is the product as in opposition to the business where customers is considered external to the organization and the product is changed to react to the customer's request (Wong, 2008).

Collis (1999) contends that higher education industry can be evaluated by same standards as by any other industry, and in fact higher education risks losing significant market share to new competitors from any other industries and early adopters of new technologies unless it adopts a more entrepreneurial and competitive approach towards meeting customer's needs".

\section{Personality and Intrapreneurship}

Before approaching the theoretical argument linking personality and intrapreneurship these two concepts are needed to be defined. Personality, as understood by Gordon Allport, a pioneer of personality psychology, is "the dynamic organization within the individual of those psychophysical systems that determine his characteristic behavior and thought" and personality forms the behaviour of a person (Lim and Melissa Ng Abdullah, 2012), while firm level entrepreneurship is known by different labels including corporate entrepreneurship(Zahra, 1993; Kuratko and Hornsby, 2011; Lekmat and Chelliah, 2014; Antoncic and Hisrich, 2001), intrapreneurship (Kuratko et al., 1990; Monnavarian and Ashena, 2009).

Despite the diversity in labels used, most of these researchers used innovativeness, risk taking and proactiveness as the dimensions of intrapreneurship, however, it is notable that most of the researcher used this term at organizational level and very less attention has been given to individual level entrepreneurial behavior in existing corporations. In this study, we utilized dimensions of intrapreneurship at individual level, which is a unique contribution in the literature. 


\section{Hypothesis development}

Personality is considered a major determinant of entrepreneurial success (Elmuti et al., 2011).The role of personality in entrepreneurship is an area of research that has resurfaced in the last decade. To extend the understanding of personality in the entrepreneurial process, meta-analyses have started to examine the link between personality and both entrepreneurial intentions and entrepreneurial performance (Rauch and Frese, 2007; Zhao et al., 2010).

Entrepreneurship research exploring the implications of the entrepreneur's personality dates back several decades. Less research has addressed the entrepreneurial intention within the confines of the organization especially the use of the five factor model of personality.

The Big Five (or Five Factor Model, FFM) personality dimensions consist of Extraversion, Neuroticism (or Emotional Stability), Agreeableness, Conscientiousness, and Openness to Experience. For years now, the Five Factor Model (FFM) of personality has dominated the literature (John et al., 2008). The reason for this is that it provides a framework for organizing personality variables (Digman, 1990). Let's have a look into the personality traits and intrapreneurial behavior.

\section{Extrovert}

Extrovert individuals are energetic, ambitious, warm, outgoing, and enthusiastic (Raja et al., 2004; Nasir et al., 2011). Individual having this characteristics are more likely to be motivated and seek for stimulation (Costa and McCrae, 1992). Extrovert take events as challenges rather than threat (Sulaiman et al., 2013). While people low on extroversion are quiet and reserved. Innovation may occur from an individual's proactive behavior such as actively participating in some task and endeavor some new ideas. On the other hand, individual who are passive and seek stimulations from others are less innovative and risk taker. The eagerness of the extrovert individuals forces them to be curious even about the routine task and this curiosity may lead towards innovation. Extrovert people always seek some novel ideas to cope up with the problems instead of avoiding the problems (Sung and Choi, 2009) which might lead to innovation. Extroversion was also found to be positively related to the risk taking (Nicholson et al., 2005). Thus, we can hypothesize that:

Hypothesis 1: Extroversion is positively related to intrapreneurial behavior.

\section{Agreeable}

People with agreeable traits of personality are trusting, cooperative and courteous (Goldberg, 1990).They tend to be tolerant, good natured and considerate (Digman, 1990; Sung and Choi, 2009). In contrary to this, people who score less on agreeable trait are suspicious, self-centered and manipulative. The innovative and creative ideas are often regarded as the challenge to the status quo and thus disrupting interpersonal relations and work process endorsed by other, which can cause an anxiety with colleagues (Sung and Choi, 2009). Individuals holding agreeable trait of personality are more concerned to care feelings of other and they avoid being abrasive and rude to others. They are more inclined towards helping behaviors, and cooperation.

Patterson et al. (2009) pointed out the importance of interaction, communication, articulation, and social networking of employees for the successful 
innovations. Matzler et al. (2011) discussed that agreeableness relates thereby increasing his or her need to reciprocate the organization for providing a supportive 601 social environment. In an empirical study Nicholson et al. (2005) found that agreeableness is negatively linked to risk taking behavior. Because of their desire of interpersonal harmony, agreeable people may face difficulty in expressing and generating their ideas that are different from others. Thus on the basis of these arguments we hypothesize:

Hypothesis 2: Agreeableness is negative related to intrapreneurial behavior.

\section{Conscientiousness}

The association between innovation and conscientiousness is somewhat vague. Innovation requires goal orientated behavior, self-discipline, hard work; these are the traits of high conscientiousness people. (Barrick and Mount, 1991).On the other side, higher level of conscientiousness is characterized as compliance with organizational norms and resistance to change, which is in opposition to the traits required for innovation (Patterson, 2002; George and Zhou, 2001). Innovation process challenges the status quo and it requires the individuals who do not care about the existing norms and innovative individual are more motivated to find new ideas to find the solution of an issue instead of repetitions of the existing norms. (Baks, 2007). Prior studies has demonstrated that individuals having high level of conscientious trait of personality are inclined to set clear goals and they put greater effort than less conscientious people in realizing those set goals (Barrick and Mount, 1991).

According to (George and Zhou, 2001) conscientious individuals are high task performer and they have higher level of job satisfaction, thus they may be less motivation to find a new opportunity. Moreover, conscientious people are found to avoid experimentation and risk taking because these may cause uncertainties and unexpected delays in their work. Raja et al. (2004) found that conscientiousness is negatively related to risk taking behavior.

Hypothesis 3: Conscientiousness is negatively related to intrapreneurial behavior.

\section{Emotional stability}

People having emotional stability traits of personality (antonym neuroticism) are considered to be calm, rand self-confident, while the neurotic people are considered to be depressed, anxious, insure and fearful (Goldberg, 1990). Individual having, neurotic personality are hopeless and less energetic to perform their work (Colbert et al., 2004).

Furthermore, individual scoring low on emotional stability are afraid of the situation in which they have probability of failing and they also lack the confidence needed to take initiative in risk taking activities (Raja et al., 2004). Contrary to this, emotional stable people are fearless, calm and confident about the task they are performing, as innovation requires ability to integrate the information effectively and efficiently, which can only be achieved when individual are calm and confident. (Sung and Choi, 2009).Thus, on the basis of these arguments we hypothesize

Hypothesis 4: Emotional stability is positively related to intrapreneurial behavior. 


\section{Openness to experience}

Openness to experience is the most researched factor of Big Five and has shown a consistent empirical relationship with creativity and innovation (Sung and Choi, 2009). Intellectual curiosity, aesthetic sense, liberals, emotional differentiated, imaginative, broad-minded and nontraditional are the traits associated with openness to experience.

Innovation is the product of novel and unfamiliar ideas. Individuals scoring high on openness to experience are more inclined to embrace the innovative and novel ideas. Individual scoring high on are able to generate and think about novel ideas that contest the status quo (George and Zhou 2001). Goldberg (1990) stated that open minded people are more eager to seek the nontraditional circumstances which help them expose to new experiences and perspectives.

Contrary to this, people scoring low on openness to experiences are more conservative and follow the traditions and norms. They are more comfort table in following the existing norms because this reduces the risk and uncertainty (Choi, 2004). It is likely, therefore, that openness is positively associated with innovation(Steel et al., 2012). Furthermore, openness was also found to be related to risk taking (Nicholson et al., 2005).

Hypothesis 5: Openness to experience is positively related to intrapreneurial behavior

\section{Method}

The survey questionnaires were emailed to more than 500 lecturers, assistant professors, professors, deans and heads of schools of social sciences department of the 20 public sector universities in Pakistan. A total number of 306 responses were given by the respondents which made the response rate around $61.2 \%$.

To elicit the responses regarding the personality traits we utilized The Big Five Inventory (BFI) developed by John et al. (1991), is a 44 item inventory that was developed to assess the big five dimensions of personality, agreeableness, conscientiousness, of extraversion, neuroticism and openness. Responses were collected on a five Likert scale measure ( 1 =strongly disagree, $5=$ strongly agree). Sixteen items out of 44 are reversed coded.

Examples of items on the BFI (all of which are preceded by I see myself as) are, "who likes to cooperate with others" (agreeableness), "who is easily distracted" (conscientiousness), "who is depressed, blue" (neuroticism), "who is outgoing, sociable" ( extroversion ) and "who has an active imagination" openness.

Dimensions of Intrapreneurship were measured by adopting Risk taking measure from Subhadra Dutta (2013), Innovativeness from Frese et al., (1997), examples of the items are "I often try to institute new work methods that are more effective for the company" (innovativeness), "I boldly move ahead with a promising new approach when others might be more cautious" Risk taking.

This research utilized the partial least square SEM (PLS-SEM) tool for the assessments of measurement and structural model. The SmartPLS2.0 software (Ringle et al., 2005) is used to execute the PLS-SEM analyses.

For the purpose of analysis of quality criteria PLS algorithm was used by adopting path weighting scheme and the settings for parameters were fixed at 300 iterations. Internal consistency, composite reliability, average variance extraction
MMCKS

602 
convergent validity was assessed for the reflective measurement model (Cenfetelli and Bassellier, 2009).The threshold values for factor leading are set as .0.5, for AVE 603 values should be $>0.50$ and for composite reliability values should be greater than 0.70. All the threshold criteria were achieved, thus helping us to move for the evaluation of structural model. Table shows the values for quality criteria of measurement model.

Table 1. Measurement Model Quality Criteria

\begin{tabular}{|c|c|c|c|c|c|c|}
\hline 2nd Order & 1st order & Items & Loadings & AVE & CR & Cronbach $\alpha$ \\
\hline \multirow[t]{10}{*}{ IB } & & & & .551 & .7823 & 0.812 \\
\hline & & rsk2 & 0.7583 & 0.5046 & 0.7532 & 0.7138 \\
\hline & & rsk3 & 0.7662 & & & \\
\hline & & rsk3 & 0.7424 & & & \\
\hline & & rsk4 & 0.6995 & & & \\
\hline & & Inno1 & 0.405 & 0.5149 & 0.8353 & 0.7481 \\
\hline & & Inno3 & 0.8196 & & & \\
\hline & & inno4 & 0.7858 & & & \\
\hline & & inno5 & 0.7735 & & & \\
\hline & & inno6 & 0.7229 & & & \\
\hline \multicolumn{7}{|c|}{ Personality traits } \\
\hline & Agreeableness & agree1 & 0.7662 & 0.5345 & 0.8129 & 0.6966 \\
\hline & & agree3 & 0.8365 & & & \\
\hline & & agree4 & 0.8284 & & & \\
\hline & & agree5 & 0.7195 & & & \\
\hline & Consciousness & consic1 & 0.8044 & 0.6611 & 0.854 & 0.7452 \\
\hline & & consic2 & 0.7922 & & & \\
\hline & & consic3 & 0.8419 & & & \\
\hline & Extroversion & Extro1 & 0.7128 & 0.5564 & 0.8316 & 0.7349 \\
\hline & & extro2 & 0.7781 & & & \\
\hline & & extro3 & 0.8632 & & & \\
\hline & & extro4 & 0.6057 & & & \\
\hline & Emotional Stab & ES1 & 0.9314 & 0.8369 & 0.9535 & 0.935 \\
\hline & & ES2 & 0.9143 & & & \\
\hline & & ES3 & 0.9001 & & & \\
\hline & & ES4 & 0.9132 & & & \\
\hline & Openness & open1 & 0.6842 & 0.6639 & 0.8868 & 0.8294 \\
\hline & & open2 & 0.8782 & & & \\
\hline & & open3 & 0.8686 & & & \\
\hline & & open4 & 0.8135 & & & \\
\hline
\end{tabular}

IB: Intraprenuerial Behavior, ES: Emotional Stability. Open: openness to experience

Source: Authors' own processing.

\section{Structural model}

The assessment of the structural model includes the check for Multicollinearity, the significance of path coefficients (bootstrapping) and R squared (Hair et al., 2014). 
Table 2. Collinearity Assessments in Structural Model

\begin{tabular}{llll}
\hline Variables & & \multicolumn{2}{l}{ Collinearity Statistics } \\
& & Tolerance & VIF \\
\hline & & \\
& Extroversion & .514 & 1.947 \\
& Agreeableness & .408 & 2.453 \\
Conscientiousness & .499 & 2.004 \\
Emotional stability & .579 & 1.728 \\
Openness & .489 & 2.046 \\
\hline
\end{tabular}

In order to check the Multicollinearity issue among the variable of the study we imported latent variable scores to IBM SPSS 22. The levels of collinearity are assessed by tolerance and variance inflation factor (VIF) values. A tolerance value of 0.20 or lower and VIF value of 5 and higher indicate a potential collinearity problem (Hair et al., 2014).The values on the table 2 indicated no Multicollinearity issue

After checking the collinearity issues the R squared values for the endogenous (dependent) variables were checked. The $\mathrm{R}$ squared value depicts the predictive capability of the model. $\mathrm{R}^{2}$ value for the endogenous construct is found as (.523).

\section{Hypothesis testing}

The relationship of structural model is determined by the path coefficient among the construct of the study (Hair et al., 2014).Critical values for two tailed and one tailed are 1.96 and 1.65 respectively. By the use of bootstrapping function of SmartPLS 2 we calculated the t statistics with 5000 re-sampling as suggested by Hair et al. (2014).

Table 3. Hypothesis Results by bootstrapping

Extro: extroversion, Emotio Stab: emotional Stability, IB: Intrapreneurial Behavior, Consic: consciousness

\begin{tabular}{lllll}
\hline Hypothesis & Beta & SE & $\begin{array}{l}\text { T } \\
\text { statistics }\end{array}$ & Decision \\
\hline extro -> IB & 0.2461 & 0.0495 & 4.1125 & supported \\
agreeabl -> IB & -0.195 & 0.0486 & 2.1285 & supported \\
consic -> IB & -0.203 & 0.0432 & 2.7746 & supported \\
Emoti Stab -> IB & 0.211 & 0.0426 & 3.7357 & supported \\
openness -> IB & 0.2037 & 0.0476 & 2.2669 & supported \\
\hline
\end{tabular}

Source: Authors' own processing.

\section{Discussions}

The current study focused on the investigation of the impact of personality traits on the intrapreneurial behavior of the employees. The study endeavored to test the IB model at micro level as the authors of the study believed that entrepreneurial behavior is Omni present in the individual, thus investigating the individual traits is imperative.

The first hypothesis was related to the association of extroversion and intraprenuerial behavior. The findings revealed a positive and significant impact of extroversion on IB. Indeed, people with high extraversion are full of energy and enthusiasm, encouraging such behaviors as seeking stimulation and proactively 
addressing problems, which should enhance creative thinking and performance (Zhao and Seibert, 2006). Extraversion was a positive predictor of performance in entrepreneurial jobs (Barrick and Mount, 1991).

The second hypothesis is regarding the relationship between agreeableness and IB. The findings revealed a negative association between the said variables, this findings is according to the proposed hypothesis, the reason of a negative relationship might be the characteristics of agreeable individual as agreeable people tend to give their strong desire for interpersonal harmony, thus they may have difficulty in generating and expressing ideas that are different from those of others or from the existing - or traditional - ways of doing things.

In third hypothesis we proposed a negative relationship between the consciousness personality traits and IB, the findings showed a negative relationship as expected because consciousness individuals have high task performance and job satisfaction levels, conscientious individuals may be less motivated to seek a problem or a new opportunity (Zhou and George, 2001). In addition, conscientious people may be mostly oriented toward carrying out the given task in an efficient and organized way rather than introducing interruptions of the given task flow by coming up with new ideas (George and Zhou, 2001)

In fourth hypothesis we proposed a positive relationship between emotional stability and IB. Results showed a positive relationship with IB, this finding is in line with (Sinha and Srivastava, 2013). It is reasonable to expect that the individual who are calm, less temperamental, less anxious and less stress prone are likely to be positively inclined towards entrepreneurial behavior. According to (García-Cabrera and García-Soto, 2009) emotional stability/less neuroticism is an enviable personality trait for intrapreneurs.

The fifth and final hypothesis proposed a positive relationship between openness to experiences and IB. This was based on the characteristics of the openness trait, individual carrying this trait are imaginative, broad minded, curious and nontraditional. Innovativeness and risk taking are regarded as challenge to the status quo. Individuals high on openness to experience are nontraditional and they keep on searching novel ideas for the solution of problems, Thus it was reasonable to expect a positive relationship between IB and openness to experience and the finding of this study endorsed our proposed hypothesis.

\section{Conclusions, implications, limitations and recommendation}

This article focused on the individual level intrapreneurial behavior in the higher educational institutes which is rather a missing link in the literature, keeping in view that in such organizations entrepreneurial activities are not formally designed and planned at inception and also not part of routine tasks. Individuals' behavior is a key to explain the intrapreneurial behavior in the confines of existing organization. Thus, in order to enhance our understanding of how to promote intrapreneurial behavior in the organizations, we need to analyze the individual characteristics, the entrepreneurship is Omni present in the humans (Sinha and Srivastava, 2013) but its manifestation depends on the individual's traits. Therefore, this study with its focus on the micro level foundations of intrapreneurial behavior is one of the first studies in this direction. 
The findings of this study have several implications in the context of HEIs. First, to enhance intrapreneurial behavior in the higher educational institutes, the management of the institutions should take positive steps to ensure that employees have personality traits which shown a significant impact on intraprenuerial behavior in this study. One strategy top management could consider is that, at the time of recruitment, preference should be given to candidates with higher levels of extroversion, openness to experience and emotional stability. However, among all the traits, the most indicative marker is extroversions followed by emotional stability. Therefore, hiring employs with high levels of extroversion and emotional stability could facilitate more intraprenuerial behavior, which ultimately, will help improve the performance of HEIs.

Like many other studies, this research also holds several limitations. First, the data was collected from the faculty members of the higher educational institutes of Pakistan, thus limiting the generalizability of the results. Therefore, it is strongly recommended to collect data from multi industries so that inference may be enhanced. Second, the study ignored the mediating or moderating effect of many contextual and other personal factors, so for the future, we suggest researchers to investigate the mediating or moderating effect of some other variables such as motivation, work environment, leader member relationship, etc.

\section{References}

Antoncic, B. and Hisrich, R.D. (2001), "Intrapreneurship", Journal of Business Venturing, Vol. 16, No. 5, pp. 495-527.

Baks, N. (2007), "Which personality traits do innovative people possess? The innovative individual Nina Bakx Master thesis Business Studies", Universiteit van amesterdam, (July), pp. 41-60.

Barrick, M.R. and Mount, M.K. (1991), "The Big Five Personality Dimensions and Job Performance: a Meta-Analysis", Personnel Psychology, Vol. 44, No.1, pp. 1-26.

Cantaragiu, R. and Hadad, S. (2014), "The importance of play in overcoming fears of entrepreneurial failure", Proceedings of the 14th European Conference on Knowledge Management, Kaunas University of Technology, September 6, 2013, Academic Conferences and Publishing International Limited, pp. 833843.

Cenfetelli, R. and Bassellier, G. (2009), "Interpretation of Formative Measurement in Information Systems Research", MIS Quarterly, Vol. 33, No. 4, pp. 689-708.

Choi, J.N. (2004), "Individual and contextual predictors of creative performance: The mediating role of psychological processes", Creativity Research Journal, Vol. 16, No. 2, pp. 187-199.

Colbert, A.E. Mount, M.K., Harter, J.K., Witt, L.A. and Barrick, M.R. (2004), "Interactive effects of personality and perceptions of the work situation on workplace deviance", The Journal of applied psychology, Vol. 89, No.4, pp. 599-609.

Collins, C.J., Hanges, P.J., and Locke, E.A., (2004), "The relationship of achievement motivation to entrepreneurial behavior: A meta-analysis", Human performance, Vol. 17, No. 1, pp. 95-117.

Covin, J.G. and Slevin, D.P., (1991), "A conceptual model of entrepreneurship as firm behavior", Entrepreneurship theory and practice, Vol. 16, No. 1, pp. 7-25.

Elmuti, D., Khoury, G. and Abdul-Rahim, B. (2011), "Entrepreneur'S Personality, 
Education and Venture Effectiveness: Perceptions of Palestinian Entrepreneurs", Journal of Developmental Entrepreneurship, Vol.16, No. 2, pp. 251-268.

García-Cabrera, A.M. and García-Soto, M.G., (2009), "A Dynamic Model of Technologybased Opportunity Recognition", Journal of Entrepreneurship, Vol. 18, No. 2, pp. 167-190.

George, J.M. and Zhou, J. (2001), "When openness to experience and conscientiousness are related to creative behavior: an interactional approach", The Journal of applied psychology, Vol. 86, No. 3, pp. 513-524.

Goldberg, L.R. (1990), "An Alternative "Description of Personality ": The Big-Five Factor Structure", Journal of personality and social psychology, Vol. 59, No. 6, pp. 1216-1229.

Goodale, J.C. Kuratko, D.F., Hornsby, J.S. and Covin, J.G. (2011), "Operations management and corporate entrepreneurship: The moderating effect of operations control on the antecedents of corporate entrepreneurial activity in relation to innovation performance. Journal of Operations Management, Vol. 29, No. 1-2, pp. 116-127.

Hadad, S., (2015), "Analytic hierarchy process analysis for choosing a corporate social entrepreneurship strategy", Management \& Marketing. Challenges for the Knowledge Society, Vol. 10, No. 3, pp. 185-207.

Hair, J., Sarstedt, M., Hopkins, L. and G. Kuppelwieser, V. (2014), "Partial least squares structural equation modeling (PLS-SEM) An emerging tool in business research", European Business Review, Vol, 26, No. 2, pp. 106-121.

Hayton, J.C., Hornsby, J.S. and Bloodgood, J. (2013), "The Contribution of HRM to Corporate Entrepreneurship: a review and agenda for future research", M@n@gement, Vol.16, No. 4, pp.381-410.

Higher Education System Strength, $\quad$ Q., 2016. http://www.topuniversities.com/system-strengthrankings/2016\#sorting=rank+custom=rank+order=desc + search $=$. Available at:http://www.topuniversities.com/system-strength rankings/2016\#sorting=rank+custom=rank+order=desc+search $=$.

Jiantreerangkool, B. and McLean, G. (2015), "Relationship of Perceived Organizational Support and Big Five Personality toward Innovation in Bangkok", Thailand Boonthipa Jiantreerangkool and Gary N. McLean. The 6th International Conference on Human Resource andOrganization Management and Development, Vol. 1, No. 1.

de Jong, J.P.J. Parker, S.K., Wennekers, S. and Wu, C. (2011), "Corporate Entrepreneurship at the Individual level: Measurement and Determinants", EIM Research Reports. Zoetermeer: EIM, (March), pp.1-27.

John, O.P., Donahue, E.M. and Kentle, R.L. (1991), "The big five inventory: Versions 4a and 54, institute of personality and social research", University of California, Berkeley, CA.

Kenney, M. and Mujtaba, B.G. (2007), "Understanding Corporate Entrepreneurship and Development: A nd development: A practitioner view of organizational intrapreneurship. Journal of Applied Management and Entrepreneurship, Vol. 72, No. 3, pp. 73-88.

Kuratko, D.F., Montagno, R.V. and Hornsby, J.S. (1990), "Developing an intrapreneurial 
assessment instrument for an effective corporate entrepreneurial environment", Strategic management journal, Vol. 11, No. 5, pp. 49-58.

Kuratko, D.F. and Hornsby, J.S. (2011), "Corporate Entrepreneurship With a Purpose: Exploring the Antecedents To Corporate Social Entrepreneurship", Academy of Management Annual Meeting Proceedings, Vol. 8, pp. 1-6.

Kuratko, D.F., Ireland, R.D. and Hornsby, J.S., (2001), "Improving firm performance entrepreneurial through corporate actions: Acordia ' S strategy entrepreneurship", The Academy of Management Executive, Vol. 15, No. 4, pp. 60-71.

Lekmat, L. and Chelliah, J. (2014), "What Are The Antecedents to Creating Sustainable Corporate Entrepreneurship in Thailand?", Contemporary Management Research, Vol. 10, No. 3, pp. 181-202.

Lim, P.S. and Melissa Ng Abdullah, L.Y. (2012), "Relationship between big-five personality domains and students academic achievement", Pertanika Journal of Social Science and Humanities, Vol. 20, No.4, pp. 973-988.

Memarzadeh Tehran, G. and Khaledi, F. (2014), "An investigation on the effects of personal characteristics on creativity and innovation", Management Science Letters, Vol. 4, No, 7, pp. 1495-1498.

Miller, D. and Friesen, P.H. (1984), "A Longitudinal Study of the Corporate Life Cycle management science, Vol. 30, No. 10, pp. 1161-1183.

Monnavarian, A. and Ashena, M. (2009), "Intrapreneurship: the role of social capital empirical evidence and proposal of a new model of intrapreneurship and its relationship with social capital", Business Strategy Series, Vol. 10, pp. 383-399.

Nasir, R. Mustaffa, M.B., Wan Shahrazad, W.S., Khairudin, R. and Syed Salim, S.S., (2011), "Parental Support, Personality, Self-efficacy as Predictors for Depression among Medical Students", Pertanika Journal of Social Sciences \& Humanities, Vol. 19, pp. 9-15.

Nicholson, N., Soane, E., Fenton-O'Creevy, M. and Willman, P. (2005), "Personality and domain-specific risk taking", Journal of Risk Research, Vol. 8, No. 2, pp. 157-176.

Phan, P.H. Wright, M., Ucbasaran, D. and Tan, W.L. (2009), "Corporate entrepreneurship: Current research and future directions". Journal of Business Venturing, Vol. 24, No. 3, pp. 197-205.

Raja, U. et al.,, 2004. The Impact of Personality on Psychological Contracts THE IMPACT OF PERSONALITY ON PSYCHOLOGICAL CONTRACTS USMAN RAJA. The Academy Of Management Journal, Vol. 47, No. 3, pp. 350-367.

Rauch, A. and Frese, M., 2007. Let's put the person back into entrepreneurship research: A meta-analysis on the relationship between business owners' personality traits, business creation, and success. European Journal of Work and Organizational Psychology, Vol. 16, No. 4, pp. 353-385.

Sinha, N. and Srivastava, K.B.L., 2013. Association of Personality, Work Values and Socio-cultural Factors with Intrapreneurial Orientation. Journal of Entrepreneurship, Vol. 22, No. 1, pp. 97-113.

Steel, G.D., Rinne, T. and Fairweather, J., 2012. Personality, Nations, and Innovation: Relationships Between Personality Traits and National Innovation Scores. Cross-Cultural Research, Vol. 46, No. 1, pp. 3-30.

Stevenson, H.H. and Jarillo, J.C., 1990. Stevenson 1990 A Paradigm of Entrepreneurship .pdf. Strategic Management Journal, Vol. 11, pp. 17-27. 
Sung, S.Y. and Choi, J.N., 2009. Do Big Five personality factors affect individual creativity? The moderating role of extrinsic motivation. Social Behavior and Personality, Vol. 37, No. 7, pp. 941-956.

609

Sulaiman, W.S.W., Kadir, N.B.A., Halim, F.W., Omar, F., Latiff, R.A. and Sulaiman, W.S.W, 2013. Structural relations between personality traits, coping strategy, social support and well-being among Adolescents. Pertanika Journal of Social Science and Humanities, Vol. 21, No. 5, pp. 121-134.

Yildiz, M.L., Namık, R. and Sokak, I., 2004. The Effects of Organizational Culture on Corporate Entrepreneurship. , Vol. 5, No. 5, pp. 35-45.

Zahra, S. A., 1995. Corporate entrepreneurship and financial performance: The case of management leveraged buyouts. Journal of Business Venturing, Vol. 10, No. 3, pp. 225-247.

Zahra, S.A. 1993. Environment, corporate entrepreneurship, and financial performance: A taxonomic approach. Journal of Business Venturing, Vol. 8, No.4, pp. 319-340.

Zahra, S.A., 1991. Predictors and financial outcomes of corporate entrepreneurship: An exploratory study. Journal of Business Venturing, 6(4), pp.259-285.

Zahra, S.A. and Covin, J.G., 1995. Contextual influences on the corporate entrepreneurship-performance relationship: A longitudinal analysis. Journal of Business Venturing, Vol. 10, No.1, pp. 43-58.

Zhao, H., Seibert, Scott and Lumpkin, G.T., 2010. Journal of Management. Journal of Management, Vol. 36, No. 2, pp. 381-404.

Zhao, H. and Seibert, S., 2006. The Big Five Personality Dimensions and Entrepreneurial Status: A Meta-Analytical Review. Journal of Applied Psychology, Vol. 91, No. 2 pp. 259-271. 